\title{
Pertumbuhan Gracilaria sp. yang Dibudidayakan Pada Tambak di Bajo Baru Dompu
}

\author{
Ulfa Yulistiana ${ }^{1)}$, Ayu Adhita Damayanti ${ }^{1)}$ dan Nunik Cokrowati ${ }^{\left.{ }^{*}\right)}$ \\ 1) Jurusan Perikanan dan Ilmu Kelautan, Fakultas Pertanian Universitas Mataram \\ *nunikcokrowati@unram.ac.id \\ DOI: https://doi.org/10.21107/rekayasa.v13i3.9013
}

\begin{abstract}
Gracilaria sp. is a seaweed that produces "agar" and has economic value. Market demand for Gracilaria sp. is quite high but has not yet been fulfilled. Gracilaria sp. has not been widely cultivated in the waters of West Nusa Tenggara Province, including Dompu. If the level of production of Gracilaria sp. high, it can improve the community's economy. So it is necessary to increase cultivation to increase the production of Gracilaria sp. This research aims to study the growth of Gracilaria sp. cultivated with different initial seed weight treatment. The research was conducted in the Bajo Baru pond, Dompu, West Nusa Tenggara. This study used a completely randomized design method consisting of five treatments with three repetitions. The treatments were: treatment A; Gracilaria sp. with initial seed weight of $100 \mathrm{gr}$ (control); treatment B: Gracilaria sp. with an initial seed weight of $375 \mathrm{~g}$; treatment C: Gracilaria sp. with an initial seed weight of $425 \mathrm{~g}$; treatment D: Gracilaria sp. with initial seed weight $475 \mathrm{~g}$; treatment E: Gracilaria sp. with initial seed weight of $575 \mathrm{~g}$. The parameters observed were absolute and daily growth, agar yield, and water quality. Cultivation and parameter observation was carried out for 30 days. Data analysis using ANOVA (Analysis of Variance) and graphs with descriptive analysis. The results showed that the initial seed weight of Gracillaria sp had no significant effect on absolute and daily growth. The best growth was obtained in treatment $E(575 \mathrm{~g})$ which gave $740 \mathrm{~g}$ absolute growth and $0.052 \mathrm{~g}$ daily growth. On the other hand, the yield value for agar shows a decreasing trend when using seeds with a higher initial weight. The yield value for the highest order was $17.56 \%$.
\end{abstract}

Keywords: seaweed, cultivation, production, growth, ANOVA

\section{PENDAHULUAN}

Rumput laut merupakan komoditas perikanan yang berpotensi untuk dikembangkan. Hal ini dikarenakan rumput laut memiliki keunggulan diantaranya mudah dalam pembudidayaannya, tidak memerlukan biaya besar, dan harganya kompetitif. Rumput laut dapat dibudidayakan secara monokultur maupun polikultur. Rumput laut juga dapat di olah sebagai bahan makanan, obat-obatan dan kosmetik. Penghasil rumput laut yang cukup dikenal di Indonesia diantaranya adalah Provinsi Nusa Tenggara Barat (NTB). Kawasan di Provinsi Nusa Tenggara Barat yang dikembangkan untuk budidaya rumput laut adalah Teluk Saleh, yaitu di Pulau Bajo, Desa Kwangko, Kecamatan Manggelewa, Kabupaten Dompu. Menurut

\section{Article History:}

Received: Nov, 13 ${ }^{\text {th }}$ 2020; Accepted: Dec, $12^{\text {th }} 2020$

Rekayasa ISSN: $2502-5325$ has been Accredited by Ristekdikti (Arjuna) Decree: No. 23/E/KPT/2019 August $8^{\text {th }}, 2019$ effective until 2023
Badan Penelitian dan Pengembangan Kelautan dan Perikanan (2016), perairan di Kabupaten Dompu yang ditetapkan sebagai kawasan perairan yang sesuai untuk budidaya rumput laut adalah kawasan perairan Teluk Saleh dengan luas sekitar $72.515 \mathrm{Ha}$ atau 99,49\%. Produksi rumput laut di Kabupaten Dompu sering mengalami penurunan, sehingga ketersediaan stok hasil produksi dari rumput laut tersebut masih belum memenuhi permintaan pasar. Badan Pusat Statistik Provinsi Nusa Tenggara Barat (2016) memiliki data bahwa produksi rumput laut di Kabupaten Dompu pada tahun 2014 adalah sebesar 22.453 ton, dan menurun pada tahun 2015 sebesar 11.088 ton.

Rumput laut yang telah dibudidayakan di NTB diantaranya adalah jenis Gracilaria sp. yang

\section{Cite this as:}

Yulistiana, U., Damayanti, A.A \& Cokrowati, N. (2020). Pertumbuhan Gracillaria sp yang Dibudidayakan pada Tambak di Bajo Baru Dompu. Rekayasa, 13 (3), 212-218. doi: https://doi.org/10.21107/rekayasa.v13i3.9013

(c) 2020 Ulfa Yuliastina, Ayu Adhita Damayanti, Nunik Cokrowati 
merupakan jenis alga merah (Rhodophyta) dan sebagai bahan baku pembuatan "agar". Namun sampai saat ini, rumput laut Gracilaria belum banyak dikembangkan. Permintaan pasar terutama dalam industri agar-agar sampai saat ini Gracilaria belum tercukupi. Permintaan pasar dunia ke Indonesia yang setiap tahunnya mencapai rata-rata $21,8 \%$. Pemenuhan permintaan hanya berkisar 13,1\% (Abdan, et al., 2016). Gracillaria merupakan komoditas rumput laut penghasil agar dan memiliki nilai ekonomis. Apabila tingkat produksi dari rumput laut Gracilaria sp. tinggi, maka dapat meningkatkan ekonomi masyarakat.

Diana et al., (2013) melakukan budidaya Gracilaria gigas di tambak dengan metode Broadcast menghasilkan rendeman agar lebih tinggi yaitu $18,3 \%$ dibandingkan dengan rendemen agar Gracilaria gigas yang dibudidayakan di laut kurang dari $10 \%$. Namun produktivitasnya lebih tinggi yang dibudidayakan di laut yaitu $12,72 \%$ dibanding dengan di tambak. Waluyo et al., (2019) menjelaskan hasil analisa rendemen agar Gracilaria verucosa yang dibudidayakan di keseluruhan tambak di Kabupaten Karawang, memiliki rendemen agar yang cukup baik yaitu 46\%. Sementara itu, Annas et al., (2019) menjelaskan hasil penelitiannya bahwa Gracilaria verucosa yang dibudidayakn di laut dengan metode Bottom off dengan perlakuan jarak tanam yang berbeda tidak memberikan pengaruh terhadap perbedaan pertumbuhan. Tetapi memberikan pengaruh terhadap rendemen agar yaitu tertinggi 24,9\% pada perlakuan jarak tanam $20 \mathrm{~cm}$. Selanjutnya, Trawanda et al., (2014) membudidayakan Gracilaria sp. di tambak dengan metode longline. Bibit yang digunakan adalah ibit hasil kultur jaringan dan bibit hasil seleksi. Rendemen agar yang dihasilkan bibit kultur jaringan 4,22 \% dan bibit hasil seleksi 3,70\%.

Budidaya Gracilaria sp belum dilakukan di tambak di wilayah Dompu. Dompu memiliki area tambak yang potensial untuk pengembangan budidaya Gracilaria sp, termasuk wilayah Bajo Baru. Saat ini tambak di area Bajo Baru digunakan untuk budidaya bandeng dan udang. Berdasarkan uraian diatas maka di perlukan penelitian tentang pertumbuhan Gracilaria sp di Bajo Baru. Tujuan penelitian ini adalah untuk menganalisis pengaruh berat bibit awal terhadap pertumbuhan Gracilaria sp. yang dibudidayakan di tambak Bajo Baru, Dompu, NTB.

\section{METODE PENELITIAN}

Penelitian ini dilaksanakan pada 16 Januari 13 Februari 2019 di perairan Teluk Saleh, yaitu di Pulau Bajo, Desa Kwangko, Kecamatan Manggelewa, Kabupaten Dompu, Provinsi Nusa Tenggara Barat. Penelitian dilakukan di tambak dengan menggunakan petak yang dibuat dari jaring hapa. Alat yang digunakan adalah tali rafia, patok bambu, baskom, alat tulis, timbangan, kamera, jarum jahit karung, jaring, gunting, pisau, gergaji, sechhi disk, termometer, kertas $\mathrm{pH}$, refraktometer, pengaduk, sendok, serok, loyang, toples plastik, panci, kompor gas, oven, gelas ukur plastik (5 L), kain saring, timbangan digital, kertas label. Bahan yang digunakan adalah bibit Gracilaria sp., aquades, kapur bubuk dan larutan $\mathrm{KCl}$.

Metode penelitian ini adalah eksperimental dengan menggunakan Rancangan Acak Lengkap (RAL) dengan 15 unit percobaan yang terdiri atas 5 perlakuan dan 3 kali ulangan. Perlakuan tersebut berupa total berat awal bibit, yaitu 100 $\mathrm{g}$ (A: Kontrol), $375 \mathrm{~g}(\mathrm{~B}), 425 \mathrm{~g}(\mathrm{C}), 475 \mathrm{~g}$ (D), dan $575 \mathrm{~g}(\mathrm{E})$. Masing -masing perlakuan diletakkan pada petak jaring pada tambak. Masing-masing perlakuan dan kontrol diulang sebanyak 3 kali, sehingga diperoleh 15 unit percobaan (Gambar $1)$.

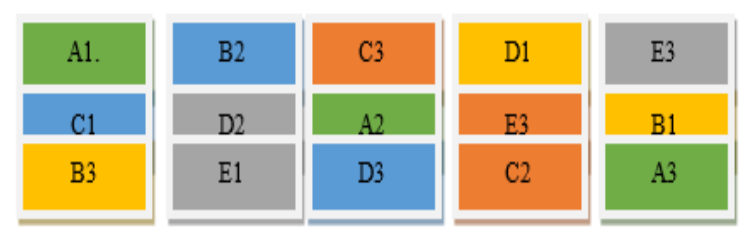

Gambar 1. Letak Satuan Perlakuan Budidaya Rumput Laut Gracilaria sp.

Hipotesis penelitian ini adalah berat awal bibit berpengaruh pada pertumbuhan Gracilaria sp. Pengukuran pertumbuhan dilakukan pada umur pemeliharaan 7, 14, 21, dan 28 hari. Variabel yang diamati selama penelitian adalah laju pertumbuhan mutlak dengan rumus perhitungan

$$
\mathrm{G}=\mathrm{Wt}-\mathrm{W} 0
$$

Keterangan:

$\mathrm{G} \quad=$ Pertumbuhan Mutlak Rata-Rata (g)；

Wt $=$ Berat Bibit Pada Akhir Penelitian (g)i

W0 = Berat Bibit Pada Awal Penelitian (g), 
Laju Pertumbuhan Harian dihitung dengan persamaan sebagai berikut.

$$
G=\left(\frac{w t}{w 0}\right)^{l / t}-1 \times 100 \%
$$

Keterangan:

$G \quad=$ Laju Pertumbuhan Harian (\%);

$W t \quad=$ Rata-Rata Bobot Akhir (g);

$W 0=$ Rata-Rata Bobot Awal (g);

$t \quad=$ Waktu Budidaya.

Pengukuran kualitas air yang dilakukan adalah suhu, salinitas, kecerahan, oksigen terlarut. Menurut Uju (2018) rendemen agar dihitung menggunakan rumus:

Rendemen $(\%)=\frac{\text { Bobot Agar }(g)}{\text { Bobot Bahan Baku }(g)} \times 100 \%$

\section{HASIL DAN PEMBAHASAN \\ Kualitas Air}

Hasil pengukuran kualitas air sebagaimana disajikan pada Tabel 1. Hasil pengukuran suhu berkisar antara $33-35^{\circ} \mathrm{C}$. Berdasarkan kisaran suhu tersebut menunjukkan bahwa tambak di Dusun Bajo Baru termasuk memiliki salinitas yang tinggi untuk pertumbuhan Gracilaria sp. Annas, et al., (2019) menjelaskan hasil penelitiannya bahwa suhu optimal untuk pertumbuhan Gracilaria verrucosa adalah $28^{\circ} \mathrm{C}$. Hasil pengukuran salinitas di Dusun Bajo Baru berkisar antara 32-35 ppt. Kisaran salinitas yang terukur selama penelitian masih dalam kisaran yang dapat ditolerir sehingga mampu mendukung pertumbuhan rumput laut. Rukmi, et al., (2012) Gracilaria sp. yang telah dibudidayakan pada penelitiannya, tumbuh optimal pada salinitas 2830 ppt.

Derajat keasaman $(\mathrm{pH})$ perairan dalam penelitian ini adalah $8 . \mathrm{pH}$ perairan relatif stabil dan berada pada kisaran normal dalam mendukung pertumbuhan rumput laut. Trawanda, et al., (2014) menjelaskan bahwa kisaran $\mathrm{pH}$ berada pada nilai 6-9 jika tambak pengisian airnya dilakukan secara alami mengikuti gerakan air pasang surut. Nilai $\mathrm{pH}$ berpengaruh pada pertumbuhan Gracilaria sp. yang dibudidayakan di tambak, sehingga pengelolaan kualitas air untuk mempertahankan nilai $\mathrm{pH}$ tersebut perlu dilakukan.

Nilai oksigen terlarut berkisar antara 9,4$13,7 \mathrm{mg} / \mathrm{l}$, nilai tersebut lebih tinggi dari kisaran normal untuk perairan tambak yang relatif memiliki gerakan air yang kecil. Nadlir, et al., (2019) menjelaskan bahwa tambak cenderung memiliki kisaran oksigen terlarut yang termasuk rendah yaitu 6,03 $\mathrm{mg} / \mathrm{L}$ - 6,28 mg/L karena gerakan air relatif kecil. Namun Gracilaria sp. yang dibudidayakan ditambak dapat menghasilkan oksigen melalui proses fotosintesis. Sehingga nilai kisaran oksigen terlarut tersebut masih tergolong layak untuk media budidaya Gracilaria sp.

Tabel 1. Nilai Parameter Kualitas Air

\begin{tabular}{llccc}
\hline No & Parameter & Satuan & Nilai & Ideal $^{*}$ \\
\hline 1 & Suhu & ${ }^{\circ} \mathrm{C}$ & $33-35$ & $20-28$ \\
2 & Salinitas & $\mathrm{Ppt}$ & $32-35$ & $15-34$ \\
3 & $\begin{array}{l}\text { Derajat } \\
\text { Keasaman }(\mathrm{pH})\end{array}$ & - & 8 & $6-9$ \\
4 & $\begin{array}{l}\text { Oksigen } \\
\text { Terlarut }\end{array}$ & $\mathrm{mg} / \mathrm{l}$ & $9,4-13,7$ & $>4$ \\
5 & Kedalaman & $\mathrm{Cm}$ & $40-80$ & $50-80$ \\
\hline
\end{tabular}

*Sumber : Zatnika (2009); Sulistijo (1996)

\section{Laju Pertumbuhan Mutlak (LPM)}

Pola pertumbuhan disetiap perlakuan cenderung naik, semakin tinggi berat bibit awal maka semakin baik laju pertumbuhannya. Pertumbuhan paling baik diperoleh pada perlakuan E (575 g) yaitu $740 \mathrm{~g}$. Kemudian diikuti oleh perlakuan B (375 g) yaitu $643,33 \mathrm{~g}$, perlakuan C (425 g) yaitu $560 \mathrm{~g}$, perlakuan D (475 g) yaitu $571,67 \mathrm{~g}$ dan terendah perlakuan A (100 g) yaitu $516,67 \mathrm{~g}$ (Gambar 2). Hasil Analysis of Variance (ANOVA) pertumbuhan mutlak memberikan pengaruh yang tidak berbeda nyata terhadap berat bibit awal Gracilaria sp (Tabel 2).

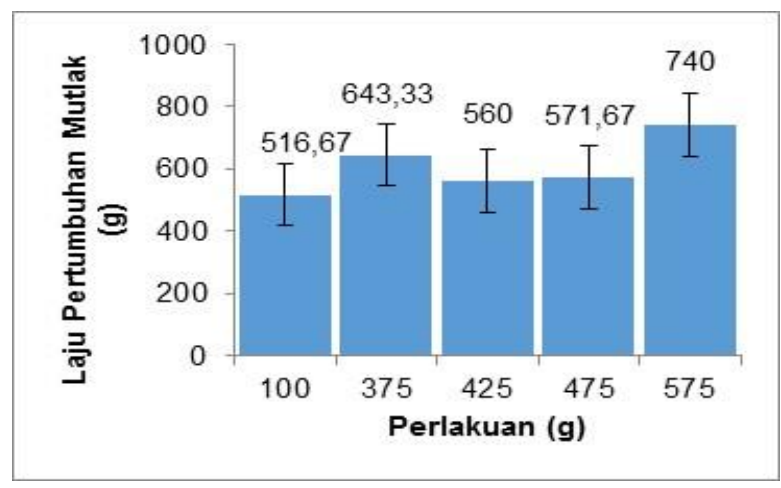

Gambar 2. Grafik pertumbuhan rata-rata mutlak Gracilaria sp

Tabel 1. Hasil uji statistik Analysis of Variance pertumbuhan Gracilaria sp.

\begin{tabular}{ccc}
\hline Perlakuan & LPM (gram) & LPH (\%) \\
\hline Kontrol A $(100 \mathrm{~g})$ & $516,67 \pm 122,20$ & $0,067 \pm 0,007$ \\
B $(375 \mathrm{~g})$ & $643,33 \pm 110,26$ & $0,156 \pm 0,211$ \\
C $(425 \mathrm{~g})$ & $560 \pm 168,00$ & $0,03 \pm 0,008$ \\
D $(475 \mathrm{~g})$ & $571,67 \pm 124,13$ & $0,029 \pm 0,004$ \\
E (575 g) & $740 \pm 37,74$ & $0,052 \pm 0,039$ \\
ANOVA & NS & NS \\
\hline
\end{tabular}

Keterangan : NS (Non Signifikan) 
Hasil penelitian menunjukkan rata-rata pertumbuhan harian pada minggu pertama relatif baik, dimana pada minggu ini proses pengadaptasian terhadap lingkungan baru dilakukan. Kemudian pada minggu ke-2, ke-3 dan ke-4 mengalami fluktuasi pertumbuhan, lebih jelas dapat dilihat pada Gambar 3.

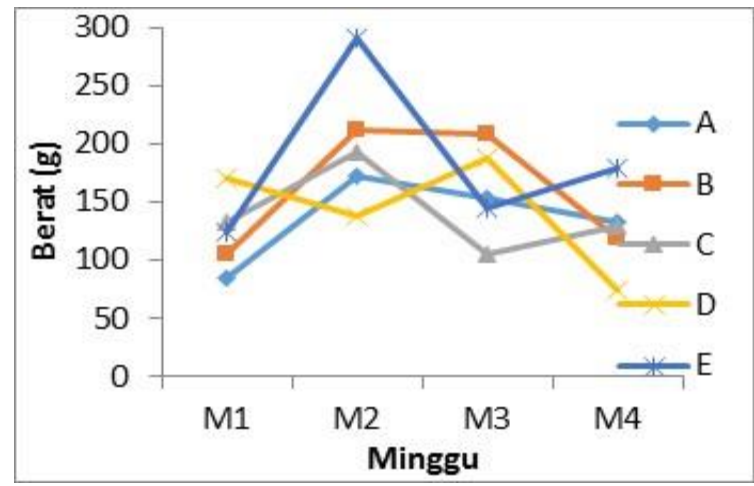

Gambar 3. Grafik Rata-Rata Laju Pertumbuhan Mingguan

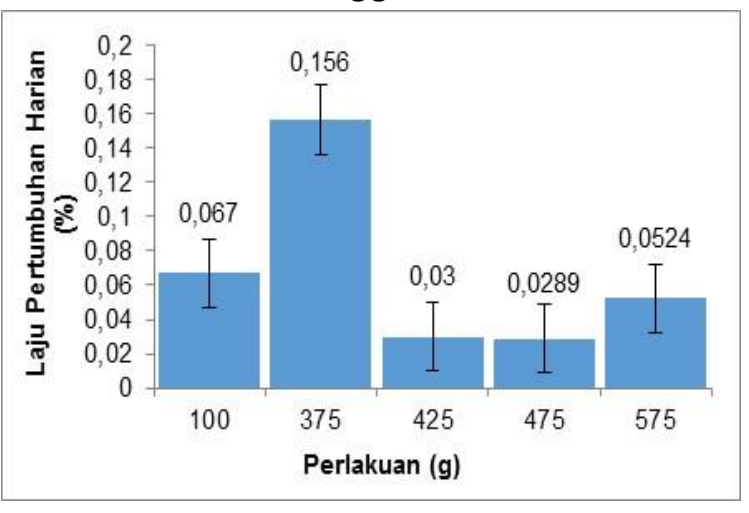

Gambar 4. Grafik Laju Pertumbuhan Harian Gracilaria sp

Hasil analisa sidik ragam (Tabel 1) menunjukkan penambahan berat Gracilaria sp. tidak memberikan kenaikan pada nilai pertumbuhan. Tidak adanya penurunan laju pertumbuhan hingga perlakuan E (575 g) dikarenakan penetrasi cahaya yang baik sehingga proses fotosintesis berlangsung dengan baik. Hasil penelitian ini menunjukkan bahwa penggunaan berat awal paling tinggi belum memperlihatkan penurunan pertumbuhan. Nutrisi yang tercukupi dengan baik menyebabkan proses pembelahan dan perpanjangan sel semakin begitu aktif sehingga dapat mempercepat laju pertumbuhannya. Hayashi, et al., (2008) menyatakan bahwa kecukupan intensitas cahaya matahari yang diterima oleh rumput laut sangat menentukan kecepatan rumput laut untuk memenuhi kebutuhan nutrien seperti karbon (C), nitrogen
(N) dan posfor (P) untuk pertumbuhan dan perkembangannya. Nurhayati, et al., (2019) menjelaskan bahwa kenaikan pertumbuhan menunjukan pertumbuhan rumput laut sudah memasuki tahap perpanjangan sel, karena tersedianya unsur hara yang cukup untuk pertumbuhan.

Berdasarkan hasil penelitian menunjukkan bahwa trend kenaikan laju pertumbuhan dengan semakin tingginya berat bibit awal. Fauziah (2017) dan Amaluddin, et al., (2017) dalam hasil penelitiannya menunjukkan bahwa perlakuan bobot awal yang besar lebih baik dibandingkan dengan berat awal yang lebih kecil. Oleh karena itu, penggunaan perlakuan berat awal bibit paling tinggi yaitu pada perlakuan E (575 g) diharapkan dapat meningkatkan produksi karena dapat lebih memaksimalkan pemanfaatan hapa tanpa mengurangi nilai pertumbuhannya.

Pertumbuhan rumput laut tidak selamanya berada pada fase baik. Namun, akan ada dimana pertumbuhan mengalami penurunan. Hal ini biasa terjadi apabila syarat penunjang pertumbuhan tidak terpenuhi. Fikri, et al., (2018) menjelaskan hasil penelitiannya bahwa Gracilaria gigas yang dibudidayakan tumbuh optimal pada kedalaman yang ideal bagi pertumbuhan rumput laut adalah berada $30-50 \mathrm{~cm}$ dari permukaan air. Pertumbuhan dipengaruhi oleh adanya serangan hama berupa kerang dan lumut yang melakat pada thallus. Tumbuhan penempel dapat menghambat proses fotosintesis selain itu juga adanya ikan herbivora seperti bandeng, udang yang memakan rumput laut.

Berdasarkan Gambar 3, rata-rata pertumbuhan mingguan Gracilaria sp. memberikan hasil fluktuatif hingga minggu terakhir (minggu ke-4). Berdasarkan hasil pengamatan di lapangan, peneliti dan pembudidaya menjadikan sebagai acuan pertumbuhan baik atau tidaknya dilihat dari minggu pertama pengamatan. Jika minggu pertama pertumbuhannya baik, maka pertumbuhan minggu selanjutnya baik pula.

Pertumbuhan optimal pada setiap minggu kemungkinan disebabkan oleh kualitas air di tambak cocok untuk pertumbuhan rumput laut. Selain itu didukung pula oleh unsur hara yang cukup, penetrasi cahaya yang stabil, suhu, salinitas, $\mathrm{pH}$, serta oksigen terlarut yang optimal. Alamsjah, et al., (2009) menjelaskan bahwa peningkatan pertumbuhan talus rumput laut 
menunjukan bahwa pertumbuhan rumput laut sudah memasuki tahap perpanjangan sel, karena tersedianya unsur hara yang cukup untuk pertumbuhan. Handayani, et al., (2004) menjelaskan bahwa pertumbuhan rumput laut akan optimal jika faktor pendukung pertumbuhan tercukupi. Faktor tersebut adalah lingkungan yang baik, faktor kimia dan fisika yang sesuai syarat pertumbuhannya serta dapat bertahan dari serangan hama dan penyakit.

\section{Laju Pertumbuhan Harian (LPH)}

Gambar 4 menunjukkan bahwa nilai rata-rata laju pertumbuhan harian Gracilaria sp. yang tertinggi terdapat pada perlakuan B ( $375 \mathrm{~g}$ ) yaitu $0,156 \%$ dan yang terendah yaitu pada perlakuan D (475 g) yaitu 0,029\%. Namun demikian hasil analisa sidik ragam menunjukkan perbedaan berat bibit awal tidak memberikan pengaruh yang nyata terhadap laju pertumbuhan harian. Nilai rata-rata Laju Pertumbuhan Harian (LPH) Gracilaria sp. menunjukkan bahwa perlakuan dengan pemberian berat bibit awal yang berbeda tidak memberikan pengaruh yang signifikan terhadap tingkat laju pertumbuhan hariannya $\left(F_{\text {hitung }}<F_{\text {tabel }}\right)$. Penggunaan berat bibit awal berbeda tidak menambah laju pertumbuhan harian namun juga tidak menurunkan laju pertumbuhan harian.

Hal tersebut disebabkan karena nutrien dapat dimanfaatkan dengan baik, sehingga makanan yang diserap oleh Gracilaria sp. cukup banyak. Selain itu pemanfaatan sinar matahari yang ada cenderung baik sehingga memudahkan proses laju penyerapan makanannya pun berlangsung lebih cepat. Menurut (Rohman, et al., 2018) menjelaskan bahwa pertumbuhan Gracilaria sp. berhubungan dengan parameter lingkungan yaitu suhu secara vertikal, penetrasi cahaya, densitas, kandungan oksigen dan unsur-unsur hara. Fotosintesis akan bertambah sejalan dengan peningkatan intensitas cahaya pada suatu nilai optimum tertentu (cahaya saturasi). Intensitas cahaya juga berkaitan langsung dengan produktivitas primer suatu perairan, semakin tinggi intensitas suatu cahaya maka semakin tinggi pula prokdutivitas primer pada suatu batasan tertentu.

Harapan, et al., (2019) menjelaskan hasil penelitiannya laju pertumbuhan harian rumput laut yang baik dan secara ekonomi menguntungkan jika lebih dari 3\%. Namun berdasarkan hasil yang didapatkan pada semua perlakuan nilai LPH kurang dari $2 \% /$ hari. Hasil yang didapatkan ini belum mendukung budidaya rumput laut.

\section{Rendemen Agar}

Hasil pengukuran rendemen agar Gracilaria sp. yang tinggi secara berurutan terdapat pada berat awal $100 \mathrm{~g}$ (A kontrol) yaitu 17,506\%, diikuti oleh berat awal $375 \mathrm{~g}$ (B) yaitu 11,49\%, kemudian berat awal $425 \mathrm{~g}(\mathrm{C})$ yaitu 8,69\%, setelah itu berat awal $475 \mathrm{~g}(\mathrm{D})$ yaitu 7,389\% dan yang terendah pada berat awal $575 \mathrm{~g}$ (E) yaitu sebesar 5,768\%. Hasil pengukuran rendemen agar Gracilaria sp. dari masing-masing perlakuan disajikan pada Gambar 5.

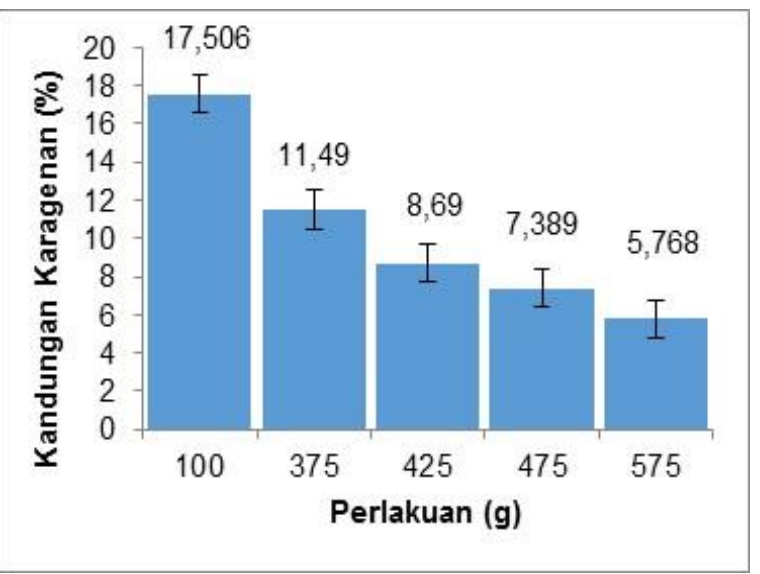

Gambar 5. Grafik Rendamen Agar Gracilaria sp

Rendemen agar yang diperoleh pada penelitian ini berkisar antara 5,768\% - 17,506\%. Rendemen agar terbaik yaitu pada perlakuan $\mathrm{A}$ $100 \mathrm{~g}$ (kontrol), namun terjadi penurunan drastis mulai terlihat pada perlakuan C (425 g). Semakin besar berat awal yang diberikan maka semakin kecil nilai rendemen agar yang dihasilkan. Santoso, et al., (2008) menyatakan berat awal memiliki pengaruh terhadap persaingan antar thallus dalam proses pemanfaatan ruang gerak, sinar matahari, maupun zat-zat hara yang diperlukan dalam proses fotosintesa dan penyerapan unsur makro nutrient dalam bentuk Nitrogen $(\mathrm{N})$ dan Fosfor $(\mathrm{P})$ yang ada diperairan sehingga menghasilkan rendemen agar yang berbeda-beda.

Pertumbuhan yang tinggi memberikan potensi nilai agar yang tinggi pula. Hal ini dikarenakan faktor pendukung pertumbuhan juga berperan dalam meningkatkan nilai agar. Oleh karena itu, walaupun hasil agar terlihat 
berbeda-beda tetapi kemungkinan bisa saja dikategorikan sama. Rendemen agar yang tinggi disebabkan oleh proses penyerapan unsur hara yang baik, dimana unsur hara tersebut dibutuhkan untuk pembentukan polisakarida, seperti agarosa dan agaropectin yang disimpan pada dinding sel sebagai bahan utama pembentukan agar. Agar terbentuk oleh campuran dua polisakarida yaitu agarosa dan agaropectin (Mackie dan Preston, 1974). Anton (2017) menjelaskan hasil penelitiannya bahwa rendemen agar pada Gracilaria sp. yang dibudidayakan dapat berbeda kandungan agarnya. Hal tersebut dipengaruhi oleh salinitas air media budidaya. Perbedaan salinitas mempengaruhi proses fisiologi dan adaptasi sehingga akan mempengaruhi proses penyerapan unsur hara.

\section{KESIMPULAN DAN SARAN}

\section{Kesimpulan}

Berdasarkan uraian hasil dan pembahasan di atas, maka dapat diperoleh kesimpulan bahwa pertumbuhan rumput laut Gracilaria sp. dengan pemberian berat bibit awal $100 \mathrm{~g}$ hingga $575 \mathrm{~g}$ tidak memberikan pengaruh yang berbeda nyata terhadap pertumbuhan rumput laut Gracilaria sp.

\section{Saran}

Budidaya Gracilaria sp dapat dilakukan di perairan laut dan di tambak dengan cara menebar rata bibit pada wadah budidaya.

\section{DAFTAR PUSTAKA}

Alamsjah, M.A., Wahyu, T., dan Anugraheny, W. P. (2009). Pengaruh Kombinasi Pupuk NPK DAN TSP Terhadap Pertumbuhan, Kadar Air dan Klorofil-a Gracilaria verrucosa . Jurnal Ilmiah Perikanan Dan Kelautan, 1(1), 103116.

Amaluddin Amaluddin, Damhuri Damhuri, S. S. (2017). Pengaruh Asal Talus Terhadap Produktivitas Eucheuma cottonii dan Eucheuma spinosum di Perairan Wakatobi. Jurnal Ampibi, 2(1). https://doi.org/DOI: 10.36709/ampibi.v2i1.5054
Annas, H., Cokrowati, N., \& Marzuki, M. (2019). Gracilaria verrucosa Growth Rate Cultivated Using Bottom Off Method. Proceeding. (Vol. 030009). https://doi.org/https://doi.org/10.1063/1.5 115613

Anton. (2017). Pertumbuhan dan Kandungan Agar Rumput Laut (Gracilaria spp) Pada Beberapa Tingkat Salinitas. Jurnal Airaha, 6(2), 54-64.

Diana,F., Kukuh, N., dan Dinar, T.S. 2014. Analisis Kualitas Rumput Laut Gracilaria gigas yang dibudidayakan Pada Habitat Laut dan Tambak Nusa Tenggara Barat. Jurnal Riset Akuakultur. Vol. 9 No. Halaman: 59-65.

Desi, A. S., Munifatul, I. dan Erma, P. 2016. Pengaruh Jarak Tanam Pada Metode Longline Terhadap Pertumbuhan dan Rendemen Agar Gracilaria verrucosa (Hudson) Papenfus. Jurnal Biologi. Volume 5 No 2, April 2016 Hal: 11-22.

Dwi Nurhayati, Wahju Tjahjaningsih, M. A. A. (2019). Pengaruh Ekstrak Alga Cokelat (Sargassum sp.) terhadap Pertumbuhan Bakteri Escherichia coli Secara In Vitro. Jurnal Ilmiah Perikanan Dan Kelautan. https://doi.org/10.20473/jipk.v3i1.11627.

Fauziah, F. (2017). Pertumbuhan Sargassum sp. Pada Tipe Habitat dan Berat Koloni Berbeda di Pantai Sakera Bintan. Fakultas Perikanan dan Ilmu Kelautan. Universitas Raja Ali Haji. TANJUNGPINANG.

Fikri, G.Y., Andi, R.R., F. (2018). Pengaruh kedalan Tanam yang Berbeda Terhadap Pertumbuhan dan Kualitas Agar Rendemen Rumput Laut (Gracilaria gigas) dengan Metode Lepas Dasar. Jurnal Perikanan Pantura (JPP), 1(2), 44-50.

Handayani,T., Sutarno dan Ahmad, D. S. (2004). Analisis Komposisi Nutrisi Rumput Laut Sargassum crassifolim J. Agard. Biofarmasi, 2(2), 1693-2242.

Harapan, S.B.S., Retno, A.M., dan Mugi, M. (2019). Performansi Pertumbuhan Rumput Laut (Kappaphycus alvarezii) dengan Menggunakan Bibit Hasil Kultur dan Non 
Kultur Jaringan di BBPBL Lampung. Jurnal Kelautan Dan Perikanan Terapan, 2(2), 9399. Retrieved from http://ejournalbalitbang.kkp.go.id/index.php/jkpt.

Hayashi, L., Yokoya, N. S., Ostini, S., Pereira, R. T. L., Braga, E. S., \& Oliveira, E. C. (2008). Nutrients removed by Kappaphycus alvarezii ( Rhodophyta, Solieriaceae ) in integrated cultivation with fi shes in recirculating water, 277, 185-191. https://doi.org/10.1016/j.aquaculture.2008. 02.024

Nadlir, A., Titik, S., Kurnia, A., Dicky, H., Alfabetian, H., C.H., dan Seto, W. (2019). Production Performance of Gracilaria verrucosa using Verticulture Method with Various Wide Planting Area in Karimunjawa. OmniAkuatika, 15(1), 47-58 https://doi.org/http://ojs.omniakuatika.net

Rohman, A., Restiana, W., dan Sri, R. (2018). Penentuan Keesuaian Wilayah Pesisisr Muara Gembong Kabupaten Bekasi Untuk Lokasi Pengembangan Budidaya Rumput
Laut dengan Pemanfaatan Sistem Informasi Geografis (SIG) Site. Jurnal Sains Akuakultur Tropis, 2, 73-82.

Rukmi, A.S., Sunaryo, Ali, D. (2012). Sistem Budidaya Rumput Laut Gracilaria verrucosa di Pertambakan dengan Perbedaan Waktu Perendaman di Dalam Larutan NPK, 1, 9094. Retrieved from http://ejournals1.undip.ac.id/index.php/jmr

Trawanda, S.A., Sri, R., dan Restiana, W. A. (2014). Kuantitas dan Kualitas Rumput Laut Gracilaria sp. Bibit Hasil Seleksi dan Kultur Jaringan dengan Budidaya Metode Longline di Tambak. Journal of Aquaculture Management and Technology, 3, 150-158. Retrieved from http://ejournals1.undip.ac.id/index.php/jamt.

Waluyo, Aef, P., Norma, A.F. dan Angky, S. 2019. Analisis Kualitas Rumput Laut Gracilaria verrucosa Di Tambak Kabupaten Karawang Jawa Barat. Jurnal Grouper. Vol 10 (1) : 3241. ISSN $2086-8480$. 